\title{
Male Breast Cancer Associated with Paget's Disease: A Case Report
}

\author{
Paget Hastalığı ile ilişkili Erkek Meme Kanseri: Olgu Sunumu \\ ๑ Türkan İkizceli, ๑ Gökçe Gülşen, • Aykut Insan, • Yıldıray Savaş, ๑ Fazilet Erözgen* \\ University of Health Sciences, Haseki Training and Research Hospital, Clinic of Radiology, Istanbul, Turkey \\ *University of Health Sciences, Haseki Training and Research Hospital, Clinic of General Surgery, Istanbul, Turkey
}

\section{Abstract}

Paget's disease of the breast is an eczematous skin disease that is usually associated with an underlying breast cancer. Male breast cancer accounts for only $1-3 \%$ of all breast malignancies. Paget's disease in men is a very rare condition of the male breast. There have been only nine reported cases of Paget's disease of the male breast between 1980 and 2015. We described a breast invasive carcinoma of a 72-year-old man who was previously diagnosed with Paget's disease.

Keywords: Paget's disease, breast cancer, male breast
Memenin Paget hastalığı ekzamatöz bir deri hastalığı olup genellikle altta yatan bir meme kanseri ile birliktedir. Erkek meme kanseri tüm meme malignitelerinin \%1-3'nü oluşturur ve Paget hastalığı ile birlikteliği ise daha da nadirdir. 1980-2015 yılları arasında erkek meme kanseri ve Paget hastalığı birlikteliği olan sadece dokuz olgu yayınlanmıştır. Bu yazıda, daha önce tanı almış Paget hastalığı olan 72 yaş erkek hastada ortaya çıkan invaziv meme karsinoma olgusu literatür eşliğinde tartışıldı.

Anahtar Sözcükler: Paget hastalığı, meme kanseri, erkek meme

\section{Introduction}

Mammary Paget's disease (PD) is a rare disease that makes up about $1 \%$ of breast cancers. Male breast cancer is also very rare, representing nearly $1.0 \%$ of all breast malignancies. Therefore, male mammary PD is extremely rare (1). Between 1980 and 2015, only nine case reports were published in the literature on male breast cancer with PD (1). Our data suggest that the prognosis of male Paget's cancer is worse than in "ordinary" male breast cancer. For this reason, it is necessary to be aware of PD with breast lesions in men (2).

In this report, we described a breast invasive carcinoma of a 72-year-old man with PD in the context of the findings of mammography (MG) and also emphasize the combination of PD and breast cancer in men.

\section{Case}

A 72-year-old man with PD was directed to the breast radiology department of our hospital for MG and breast ultrasonography (US). He had a skin lesion on both of his breast nipples as well as itching, redness, and a palpable breast mass on his right breast (Figure 1). Physical examination revealed a clearly exudative erythema, reddish, enlarged nipple and edema around the areola. No right axillary lymph node was palpable. First of all, for the determination of breast cancer and evaluation of the breast parenchyma changes, MG (IMS Giotto MD digital radiography and Tomosynthesis, Bologna, Italy) and breast US were performed. Right MG confirmed the mass including microcalcification underlying nipple (Figure 2). His left MG was normal. High-frequency grayscale US of the breast using a linear probe $(6-13 \mathrm{MHz}$ ) (Hitachi Medco's Digital Ultra Sound Examination Device, HI VISION Avius, Tokyo, Japan) revealed $2 \mathrm{~cm}$ solid mass that had ill-defined borders and posterior acoustic shadowing in the retroareolar area (BIRADS-4c). Informed consent 


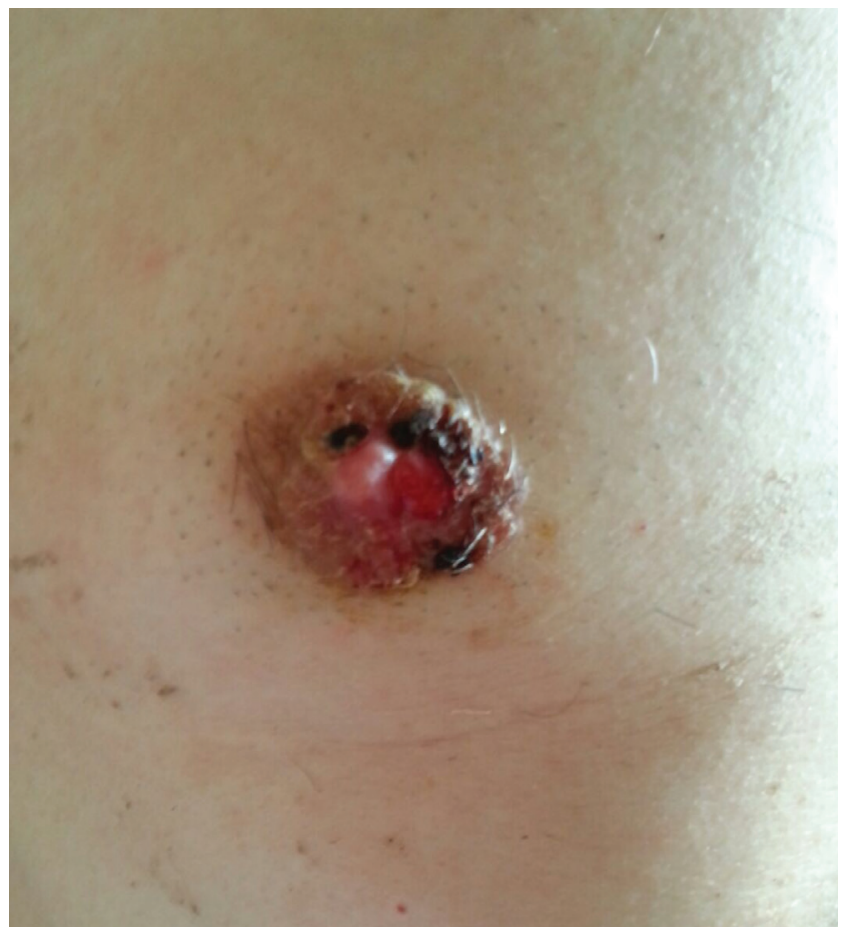

Figure 1. The skin lesion that has redness and a palpable breast mass on his right breast

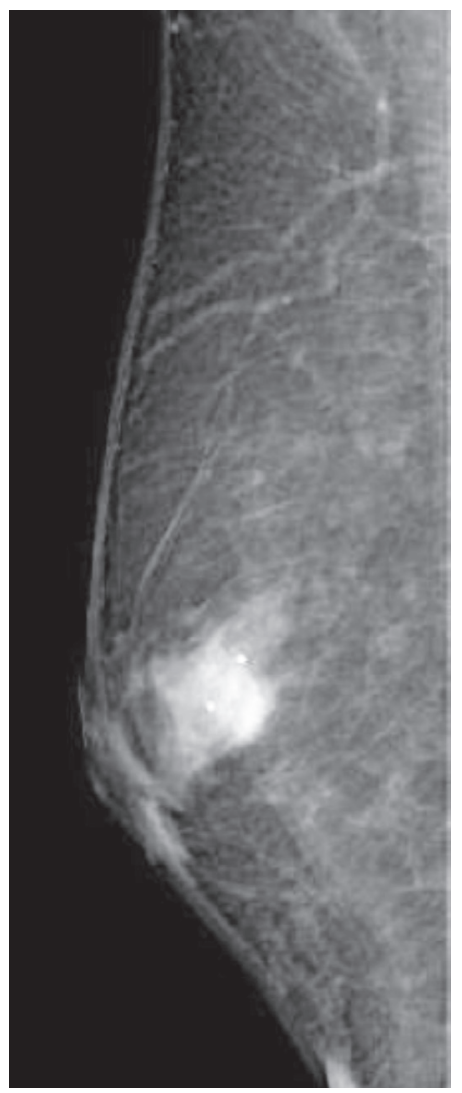

Figure 2. Right MLO mammography showed $2 \mathrm{~cm}$ mass in the retroareolar area with microcalcifications was obtained from the patient for the biopsy and he underwent the right breast biopsy (14G automatic coreneedle, Geotek, Turkey). The histopathology showed an invasive ductal carcinoma with PD. He underwent a right modified radical mastectomy and right axillary dissection.

\section{Discussion}

PD of the breast was first described, in 1874, by Sir James (3), whereas the first case of PD in a male was described by Elbogen in 1908 (4). PD of the breast in men is quite rare occurrence. Because of the rarity of breast cancer in male patients, our data in men is usually based on case reports and female patients (4). For men, the lifetime risk of getting breast cancer is about $0.8 \%$. But in the relative minority of cases in men, no studies have fairly compared cancer incidence in male patients with PD (5). To our knowledge, between 1980 and 2015, only nine case reports were published in the literature about male breast cancer with PD (1). PD of the breast appears as a skin lesion of the nipple and areola. It must be distinguished from skin lesions or carcinomatous lesions (6). The diagnosis of underlying cancer may be delayed. The clinical appearance of PD is usually characteristic and should alert the clinician to the likelihood of confusion about breast cancer. Suspect cases should be evaluated radiologically by clinicians (3). In clinically suspected cases, MG is the first method to detect an underlying malignancy and to show the mass if there are any positive findings. This may be followed by breast sonography and then maybe magnetic resonance imaging (MRI) especially if MG findings are negative. MG shows skin and nipple changes, malignant calcifications, a mass or masses, architectural distortion or asymmetry. However, MG can be normal in 22-50\% of patients, based on a group of women with PD (7). US is sometimes necessary and should be considered a part of the initial evaluation, especially when MG is negative. However, most of the time, the findings are nonspecific and cases of infection. US examination may reveal hypoechoic areas, masses, skin thickening or dilated ducts (8). In our case, he was already a follow-up PD patient. Both MG and US showed a mass on his right breast. MG also showed pathologic microcalcifications.

Studies in females have shown that MRI is more sensitive in detect underlying malignancy. However, male patients generally have little or no breast tissue. For this reason, $\mathrm{MG}$ is more sensitive in detecting a mass in men than in women. MRI may have little additional sensitivity over MG in most male patients (7).

Histologically, $90 \%$ of male breast cancers are invasive ductal carcinomas (9). $46 \%$ of Paget's cases without a mass is usually found in only $38 \%$ with ductal carcinoma in situ $(9,10)$. In our case, we diagnosed invasive ductal carcinoma by biopsy. 
In conclusion, the case highlights the need to be vigilant when new skin lesions are present in male patients with PD and the clinician should be alert to the likelihood of an underlying carcinoma, which should be evaluated radiologically. Malignancy is the most important differential diagnosis.

\section{Authorship Contributions}

Surgical and Medical Practices: T.I., F.E. Concept: T.i. Design: T.i. Data Collection or Processing: T.i., A.I. Analysis or Interpretation: T.I., F.E., Y.S. Literature Search: T.I., G.G. Writing: T.i.

Conflict of Interest: No conflict of interest was declared by the authors.

Financial Disclosure: The authors declared that this study has received no financial support.

\section{References}

1. Akita M, Kusunoki $N$, Nakajima T, et al. Paget's disease of the male breast: a case report. Surg Case Rep 2015;1:103.

2. Piekarski J, Kubiak R, Jeziorski A. Clinically silent Paget disease of male nipple. J Exp Clin Cancer Res 2003;22:495-6.
3. Günhan-Bilgen I, Oktay A. Paget's disease of the breast: clinical, mammographic, sonographic and pathologic findings in 52 cases. Eur J Radiol 2006;60:256-63.

4. Adams SJ, Kanthan R. Paget's disease of the male breast in the 21st century: A systematic review. Breast 2016;29:14-23.

5. El Harroudi T, Tijami F, El Otmany A, Jalil A. Paget disease of the male nipple. J Cancer Res Ther 2010;6:95-6.

6. Lopes Filho LL, Lopes IM, Lopes LR, Enokihara MM, Michalany AO, Matsunaga N. Mammary and extramammary Paget's disease. An Bras Dermatol 2015;90:225-31.

7. Lim HS, Jeong SJ, Lee JS, et al. Paget disease of the breast: mammographic, US, and MR imaging findings with pathologic correlation. Radiographics 2011;31:1973-87.

8. Karakas C. Paget's disease of the breast. J Carcinog 2011;10:31.

9. Ucar AE, Korukluoglu B, Ergul E, Aydin R, Kusdemir A. Bilateral Paget disease of the male nipple: first report. Breast 2008;17:317-8.

10. Fouad D. Paget's disease of the breast in a male with lymphomatoid papulosis: a case report. J Med Case Rep 2011:5:43. 